\title{
Pertumbuhan Bibit Buah Naga (Hylocereus polyrhizus) pada Berbagai Panjang Stek dan Komposisi Media Tanam
}

\section{Growth of Dragon Fruits Seeds (Hylocereus Polyrhizus) at Various Lengths of Stek and Composition of Media Planting}

\author{
M. Iqbal' ${ }^{1)}$, Nur Hafizah' ${ }^{2)}$ dan Zarmiyeni' ${ }^{3)}$ \\ Program Studi Agroteknologi, Sekolah Tinggi Ilmu Pertanian Amuntai \\ ${ }^{1)}$ m.iqbal7769@yahoo.com \\ 2)fifi_bjm@yahoo.com \\ 3) Zarmiyenilg@yahoo.co.id
}

\begin{abstract}
ABSTRAK
Buah naga merupakan salah satu tanaman jenis kaktus yang cukup populer karena rasanya yang manis dan bentuknya yang unik serta menarik. Perbanyakan bibit buah naga biasa dilakukan dengan stek dan salah satu permasalahan dalam penyediaan bibit buah naga adalah media tanam. Penelitian ini bertujuan mengetahui (i) pengaruh interaksi berbagai panjang stek dan komposisi media tanam, (ii) pengaruh berbagai panjang stek, (iii) pengaruh berbagai komposisi media tanaman, (iv) interaksi terbaik antara berbagai panjang stek dan komposisi media tanam, (v) panjang stek terbaik dan (vi) komposisi media terbaik pada budidaya tanaman buah naga. Penelitian ini dilaksanakan di Desa Haur Gading Kecamatan Batang Alai Utara Kabupaten Hulu Sungai Tengah dari bulan Mei-Agustus 2018, menggunakan Rancangan Acak Kelompok (RAK) Faktorial 2 faktor. Faktor pertama adalah panjang stek dengan 4 taraf: $p_{1}=35 \mathrm{~cm}, p_{2}=40 \mathrm{~cm}, p_{3}=45 \mathrm{~cm}, p_{4}=50 \mathrm{~cm}$. Faktor kedua adalah komposisi media tanam dengan 3 taraf: $k_{1}=1,5 \mathrm{~kg}$ tanah : 0,0 kg pupuk kotoran wallet : 1,5 $\mathrm{kg}$ pasir, $k_{2}=1,0 \mathrm{~kg}$ tanah $: 1,0 \mathrm{~kg}$ pupuk kotoran wallet : 1,0 kg pasir, $k_{3}=0,5 \mathrm{~kg}$ tanah : 1,5 $\mathrm{kg}$ pupuk kotoran wallet : 1,5 $\mathrm{kg}$ pasir. Hasil penelitian menunjukan bahwa interaksi panjang stek dengan komposisi media tanam tidak berpengaruh terhadap pertumbuhan, sedangkan faktor tunggal panjang stek tidak berpengaruh pada semua variabel pengamatan kecuali panjang tunas berpengaruh nyata pada minggu 12 MST dan faktor komposisi media tanam berpengaruh terhadap pertumbuhan bibit buah naga.
\end{abstract}

Kata Kunci: Buah naga, panjang stek, komposisi, media tanam.

\begin{abstract}
Dragon fruit is one of the cactus plants, which is quite popular because of its sweet taste and unique and interesting shape. Propagation of dragon fruit seeds is usually done by cuttings, and one of the problems in the supply of dragon fruit seeds is the planting medium. This study aims to determine (i) the effect of the interaction of various cuttings lengths and composition of the planting medium, (ii) the effect of various lengths of cuttings, (iii) the influence of various plant media compositions, (iv) the best interactions between various cuttings and composition of planting media, $(v)$ the best length of cuttings and (vi) the best media composition in dragon fruit cultivation. This study was conducted in Haur Gading Village, Batang Alai Utara District, Hulu Sungai Tengah Regency from May-August 2018, using Factorial Randomized Block Design (RBD) 2 factors. The first factor is the length of cuttings with 4 levels: $p_{1}=35$ $\mathrm{cm}, p_{2}=40 \mathrm{~cm}, p_{3}=45 \mathrm{~cm}, p_{4}=50 \mathrm{~cm}$. The second factor is the composition of the planting medium with 3 levels: $k_{1}=1.5 \mathrm{~kg}$ of soil: $0.0 \mathrm{~kg}$ wallet dirt fertilizer: $1.5 \mathrm{~kg}$ of sand, $k_{2}=1.0 \mathrm{~kg}$ of soil: $1.0 \mathrm{~kg}$ of wallet dirt fertilizer: $1,0 \mathrm{~kg}$ of sand, $k_{3}=0.5 \mathrm{~kg}$ of soil: $1.5 \mathrm{~kg}$ wallet dirt fertilizer: $1.5 \mathrm{~kg}$ of sand. The results showed that the interaction of the length of cuttings with the composition of the planting medium had no effect on growth, while the single length factor of the cuttings had no effect on all observation variables except the shoot length had a significant effect on week $12 \mathrm{WAP}$, and the composition of planting media influenced the growth of dragon fruit seeds.
\end{abstract}

Keywords: Dragon fruit, cuttings length, composition, planting media.

PENDAHULUAN
Buah naga (Hylocereus polyrhizus) merupakan salah satu tanaman jenis kaktus yang tergolong baru di Indonesia dan cukup 
populer karena rasanya yang manis dan bentuknya yang unik serta menarik. Buah eksotik ini memiliki nilai ekonomi yang tinggi karena memiliki banyak khasiat kesehatan untuk berbagai penyakit dan bermanfaat sebagai bahan baku industri pengolahan makanan, minuman, kosmetik serta produk (Emil, 2011).

Budidaya tanaman yang memiliki beragam jenis 1.736 diantaranya buah naga berdaging putih, berdaging merah dan berdaging kuning ini, di Indonesia dapat berkembang dengan baik karena iklim tropis di Indonesia memberi kondisi lingkungan yang sesuai bagi pertumbuhannya (Yunanda, 2015).

Peningkatan produksi buah naga dapat dilakukan dengan pengadaan bibit yang berkualitas baik. Tanaman buah naga dapat diperbanyak secara generatif dengan biji dan secara vegetatif dengan menggunakan stek cabang atau batang. Perbanyakan dengan stek batang mempunyai beberapa keuntungan antara lain lebih praktis, cepat berbuah, sifat turunan sama dengan induk sehingga sifat keunggulan induk dapat dipertahankan (Novitasari et. al., 2015).

Berdasarkan hasil penelitian Sparta et. al., (2012) diketahui bahwa waktu muncul tunas, jumlah tunas, panjang tunas dan panjang akar pada stek buah naga dipengaruhi secara nyata oleh panjang stek. Pertumbuhan stek yang terbaik dapat terlihat pada panjang stek di atas $20 \mathrm{~cm}$.

Winten et. al., (2017) dari hasil penelitiannya diketahui bahwa perlakuan panjang stek bibit buah naga tidak berpengaruh terhadap semua parameter yang diamati, namun panjang stek $30 \mathrm{~cm}$ cenderung paling cepat tumbuh walaupun untuk parameter panjang tunas, panjang akar dan jumlah akar cenderung lebih rendah dari perlakuan stek $40 \mathrm{~cm}$.

Menurut Kristanto (2009) agar tanaman tumbuh dengan baik dan dapat memberikan hasil yang optimal maka media tanam harus subur, gembur dan mengandung bahan organik. Perkembangan akar sangat dipengaruhi oleh struktur tanah, air tanah dan aerasi di dalam tanah oleh sebab itu diperlukan komposisi media tanam yang tepat antara tanah, pasir dan pupuk kandang.
Berdasarkan hasil penelitian Yanti (2008) menunjukan bahwa media tanam paling baik untuk pertumbuhan stek tanaman buah naga adalah media tanam pasir : arang sekam : pupuk kandang $(1: 1: 1)$ dengan pengamatan saat kemunculan tunas tercepat 36,71 HST, panjang tunas terpanjang $39,27 \mathrm{~cm}$, jumlah tunas terbanyak 1,76 buah, berat segar tanaman tertinggi 138,07 $\mathrm{g}$ dan berat kering tanaman tertinggi 50,82 g.

Penelitian Arifin, et. al., (2015) menghasilkan perlakuan macam pupuk organik dan panjang stek berpengaruh nyata terhadap pertumbuhan tanaman buah naga pada variabel panjang tunas, berat segar akar, berat kering akar, berat segar tunas, dan berat kering tunas. Pada perlakuan pupuk kandang kotoran ayam : jerami : daun lamtoro $(1: 1$ : 1) dengan panjang stek $30 \mathrm{~cm}$ adalah terbaik karena menghasilkan berat segar akar, berat kering akar, berat segar tunas dan berat kering tunas tertinggi.

Tujuan penelitian ini adalah untuk mengetahui (i) pengaruh interaksi berbagai panjang stek dan komposisi media tanam pada budidaya tanaman buah naga, (ii) pengaruh berbagai panjang stek pada budidaya tanaman buah naga, (iii) pengaruh berbagai komposisi media tanaman pada budidaya tanaman buah naga, (iv) interaksi terbaik antara berbagai panjang stek dan komposisi media tanam pada budidaya tanaman buah naga, (v) panjang stek terbaik pada budidaya tanaman buah naga dan (vi) komposisi media terbaik pada budidaya tanaman buah.

\section{METODE PENELITIAN}

Penelitian ini dilaksanakan di Desa Haur Gading Kecamatan Batang Alai Utara Kabupaten Hulu Sungai Tengah dari bulan Mei - Agustus 2018. Bahan yang digunakan adalah stek batang buah naga merah, tanah, pupuk kotoran walet, pasir, polybag, rootone$\mathrm{F}$, fungisida, pestisida, air, plang penelitian, lebel dan sungkup plastik. Alat yang digunakan adalah cangkul, sekop, parang, meteran, gunting, sendok takar, ayakan, timbangan, ember, penggaris, palu, gergaji, alat tulis dan kamera. Penelitian ini 
menggunakan Rancangan Acak Kelompok (RAK) Faktorial 2 faktor. Faktor pertama adalah panjang stek dengan 4 taraf: $\mathrm{p}_{1}=35$ $\mathrm{cm}, \mathrm{p}_{2}=40 \mathrm{~cm}, \mathrm{p}_{3}=45 \mathrm{~cm}, \mathrm{p}_{4}=50 \mathrm{~cm}$. Faktor kedua adalah komposisi media tanam dengan 3 taraf: $\mathrm{k}_{1}=1,5 \mathrm{~kg}$ tanah : $0,0 \mathrm{~kg}$ pupuk kotoran wallet : $1,5 \mathrm{~kg}$ pasir, $\mathrm{k}_{2}=1,0 \mathrm{~kg}$ tanah : $1,0 \mathrm{~kg}$ pupuk kotoran wallet : $1,0 \mathrm{~kg}$ pasir, $\mathrm{k}_{3}=0,5 \mathrm{~kg}$ tanah : $1,5 \mathrm{~kg}$ pupuk kotoran wallet : $1,5 \mathrm{~kg}$ pasir. keseluruhan percobaan terdapat 12 kombinasi perlakuan yang diulang sebanyak 3 kali sehingga didapatkan 36 satuan percobaan. Setiap satuan percobaan terdiri dari 6 tanaman sampel. Pengamatan yang dilakukan adalah waktu munculnya tunas, jumlah tunas, panjang tunas, panjang akar dan berat basah akar. Analisis statistik yang dilakukan adalah uji kehomogenan ( $\alpha: 5 \%)$ uji $F(\alpha: 5 \%$ dan $\alpha: 1 \%)$, uji $F(\alpha: 5 \%$ dan $\alpha: 1 \%)$ dan uji beda rata-rata DMRT $(\alpha: 5 \%)$.

\section{HASIL DAN PEMBAHASAN}

\section{Hasil}

\section{Waktu Muncul Tunas}

Berdasarkan Hasil analisis ragam diketahui bahwa interaksi antara panjang stek dengan media tanam tidak berpengaruh, sedangkan perlakuan tunggal panjang stek tidak berpengaruh dan perlakuan tunggal media tanam berpengaruh nyata terhadap waktu munculnya tunas tanaman buah naga. Hasil uji rata-rata waktu munculnya tunas tanaman buah naga pada perlakuan media tanam disajikan pada Tabel 1.

Tabel 1. Hasil uji rata-rata waktu muncul tunas tanaman buah naga pada perlakuan media tanam

\begin{tabular}{cc}
\hline Perlakuan & Waktu muncul tunas (hari) \\
Komposisi media tanam $(\mathrm{K})$ & $34,83^{\mathrm{b}}$ \\
$\mathrm{k}_{1}$ & $22,83^{\mathrm{a}}$ \\
$\mathrm{k}_{2}$ & $22,58^{\mathrm{a}}$ \\
$\mathrm{k}_{3}$ & . \\
\hline
\end{tabular}

Keterangan: Nilai rata-rata yang diikuti oleh huruf yang sama pada kolom yang sama menunjukan perlakuan tersebut tidak berbeda berdasarkan DMRT pada taraf 5\%

Dari Tabel 1 terlihat bahwa perlakuan $\mathrm{k}_{3}$ menunjukan waktu muncunya tunas paling cepat yaitu 22,58 hari yang tidak berbeda dengan perlakuan $\mathrm{k}_{2}$, tetapi berbeda dengan perlakuan $\mathrm{k}_{1}$.

\section{Jumlah Tunas}

Berdasarkan hasil analisis ragam diketahui bahwa interaksi antara panjang stek dengan media tanam tidak berpengaruh, sedangkan perlakuan tunggal panjang stek tidak berpengaruh dan perlakuan tunggal media tanam berpengaruh nyata terhadap jumlah tunas tanaman buah naga. Hasil uji rata-rata jumlah tunas tanaman buah naga pada perlakuan media tanam disajikan pada Tabe 2.

Tabel 2. Hasil uji rata-rata jumlah tunas tanaman buah naga minggu 2, 4, 6, 8, 10, dan 12 MST pada perlakuan media tanam

\begin{tabular}{ccccccc}
\hline \multirow{2}{*}{ Perlakuan } & \multicolumn{5}{c}{ Rata-rata jumlah tunas (buah) } \\
\cline { 2 - 7 } & $2 \mathrm{MST}$ & $4 \mathrm{MST}$ & $6 \mathrm{MST}$ & $8 \mathrm{MST}$ & $10 \mathrm{MST}$ & $12 \mathrm{MST}$ \\
\hline $\mathrm{k}_{1}$ & 0,00 & $0,07^{\mathrm{b}}$ & $0,54^{\mathrm{b}}$ & $0,70^{\mathrm{b}}$ & $0,66^{\mathrm{b}}$ & $0,70^{\mathrm{b}}$ \\
$\mathrm{k}_{2}$ & 0,00 & $0,33^{\mathrm{a}}$ & $1,01^{\mathrm{a}}$ & $1,36^{\mathrm{a}}$ & $2,12^{\mathrm{a}}$ & $2,15^{\mathrm{a}}$ \\
$\mathrm{k}_{3}$ & 0,00 & $0,47^{\mathrm{a}}$ & $1,14^{\mathrm{a}}$ & $1,37^{\mathrm{a}}$ & $2,18^{\mathrm{a}}$ & $2,29^{\mathrm{a}}$ \\
\hline
\end{tabular}

Keterangan: Nilai rata-rata yang diikuti oleh huruf yang sama pada kolom yang sama menunjukan perlakuan tersebut tidak berbeda berdasarkan DMRT pada taraf 5\%

Dari Tabel 2 terlihat bahwa pada minggu 2 MST perlakuan $\mathrm{k}_{1}, \mathrm{k}_{2}$ dan $\mathrm{k}_{3}$ belum tumbuh. Pada 4 MST perlakuan $\mathrm{k}_{3}$ menunjukan jumlah tunas tanaman paling 
banyak yaitu 0,47 buah yang tidak berbeda dengan perlakuan $\mathrm{k}_{2}$ dan berbeda dengan perlakuan $\mathrm{k}_{1}$. Pada 6 MST perlakuan $\mathrm{k}_{3}$ menunjukan jumlah tunas tanaman paling banyak yaitu 1,14 buah yang tidak berbeda dengan perlakuan $\mathrm{k}_{2}$ dan berbeda dengan perlakuan $\mathrm{k}_{1}$. Pada 8 MST perlakuan $\mathrm{k}_{3}$ menunjukan jumlah tunas tanaman paling banyak yaitu 1,37 buah yang tidak berbeda dengan perlakuan $\mathrm{k}_{2}$ dan berbeda dengan perlakuan $\mathrm{k}_{1}$. Pada 10 MST perlakuan $\mathrm{k}_{3}$ menunjukan jumlah tunas tanaman paling banyak yaitu 2,18 buah yang tidak berbeda dengan perlakuan $\mathrm{k}_{2}$ dan berbeda dengan perlakuan $\mathrm{k}_{1}$. Pada 12 MST perlakuan $\mathrm{k}_{3}$ menunjukan jumlah tunas tanaman paling banyak yaitu 2,29 buah yang tidak berbeda dengan perlakuan $\mathrm{k}_{2}$ dan berbeda dengan perlakuan $\mathrm{k}_{1}$.

\section{Panjang Tunas}

Berdasarkan hasil analisis ragam diketahui bahwa interaksi antara panjang stek dengan media tanam tidak berpengaruh, sedangkan perlakuan tunggal panjang stek berpengaruh nyata pada 12 MST dan perlakuan tunggal media tanam berpengaruh nyata terhadap panjang tunas tanaman buah naga. Hasil uji rata-rata panjang tunas tanaman buah naga pada perlakuan media tanam disajikan pada Tabel 3 .

Tabel 3. Hasil uji rata-rata panjang tunas tanaman buah naga minggu 2, 4, 6, 8, 10 dan 12 MST pada perlakuan media tanam

\begin{tabular}{ccccccc}
\hline \multirow{2}{*}{ Perlakuan } & \multicolumn{5}{c}{ Rata-rata panjang tunas (cm) } \\
\cline { 2 - 7 } & 2 MST & 4 MST & 6 MST & 8 MST & 10 MST & 12 MST \\
\hline $\mathrm{k}_{1}$ & 0,00 & $0,43^{\mathrm{b}}$ & $1,14^{\mathrm{b}}$ & $2,35^{\mathrm{b}}$ & $3,30^{\mathrm{b}}$ & $3,76^{\mathrm{b}}$ \\
$\mathrm{k}_{2}$ & 0,00 & $1,23^{\mathrm{ab}}$ & $2,80^{\mathrm{a}}$ & $5,08^{\mathrm{a}}$ & $6,72^{\mathrm{a}}$ & $7,38^{\mathrm{a}}$ \\
$\mathrm{k}_{3}$ & 0,00 & $2,47^{\mathrm{a}}$ & $3,27^{\mathrm{a}}$ & $5,35^{\mathrm{a}}$ & $6,97^{\mathrm{a}}$ & $7,86^{\mathrm{a}}$ \\
\hline
\end{tabular}

Keterangan: Nilai rata-rata yang diikuti oleh huruf yang sama pada kolom yang sama menunjukan perlakuan tersebut tidak berbeda berdasarkan DMRT pada taraf 5\%

Dari Tabel 3 terlihat bahwa pada 2 MST perlakuan $\mathrm{k}_{1}, \mathrm{k}_{2}$ dan $\mathrm{k}_{3}$ belum tumbuh. Pada 4 MST perlakuan $\mathrm{k}_{3}$ menunjukan panjang tunas tanaman paling panjang yaitu $2,47 \mathrm{~cm}$ yang berbeda dengan perlakuan $\mathrm{k}_{2}$ dan $\mathrm{k}_{1}$. Pada 6 MST perlakuan $\mathrm{k}_{3}$ menunjukan panjang tunas tanaman paling panjang yaitu $3,27 \mathrm{~cm}$ yang tidak berbeda dengan perlakuan $\mathrm{k}_{2}$ dan berbeda dengan perlakuan $\mathrm{k}_{1}$. Pada 8 MST perlakuan $\mathrm{k}_{3}$ menunjukan panjang tunas tanaman paling panjang yaitu $5,35 \mathrm{~cm}$ yang tidak berbeda dengan perlakuan $\mathrm{k}_{2}$ dan berbeda dengan perlakuan $\mathrm{k}_{1}$. Pada 10 MST perlakuan $\mathrm{k}_{3}$ menunjukan panjang tunas tanaman paling panjang yaitu $6,97 \mathrm{~cm}$ yang tidak berbeda dengan perlakuan $\mathrm{k}_{2}$ dan berbeda dengan perlakuan $\mathrm{k}_{1}$. Pada $12 \mathrm{MST}$ perlakuan $\mathrm{k}_{3}$ menunjukan panjang tunas tanaman paling panjang yaitu $7,86 \mathrm{~cm}$ yang tidak berbeda dengan perlakuan $\mathrm{k}_{2}$ dan berbeda dengan perlakuan $\mathrm{k}_{1}$.

\section{Panjang Akar}

Berdasarkan hasil analisis ragam diketahui bahwa interaksi antara panjang stek dengan media tanam tidak berpengaruh, sedangkan perlakuan tunggal panjang stek tidak berpengaruh dan perlakuan tunggal media tanam berpengaruh nyata terhadap panjang akar tanaman buah naga. Hasil uji rata-rata panjang akar buah naga pada perlakuan media tanam disajikan pada Tabel 4. Dari Tabel 4 terlihat bahwa perlakuan $\mathrm{k}_{3}$ menunjukan panjang akar paling panjang yaitu 23,29 $\mathrm{cm}$ yang berbeda dengan perlakuan $\mathrm{k}_{2}$ dan $\mathrm{k}_{1}$.

Tabel 4. Hasil uji rata-rata panjang akar tanaman buah naga pada perlakuan media tanam 


\section{Perlakuan}

Komposisi media tanam (K)

Panjang akar (cm)

$\mathrm{k}_{1}$

$17,58^{\mathrm{a}}$

$\mathrm{k}_{2}$

$19,58^{\mathrm{a}}$

$\mathrm{k}_{3}$

Keterangan: Nilai rata-rata yang diikuti oleh huruf yang sama pada kolom yang sama menunjukan perlakuan tersebut tidak berbeda berdasarkan DMRT pada taraf 5\%

\section{Berat Basah Akar}

Berdasarkan hasil analisis ragam diketahui bahwa interaksi antara panjang stek dengan media tanam tidak berpengaruh, sedangkan perlakuan tunggal panjang stek tidak berpengaruh dan perlakuan tunggal media tanam tidak berpengaruh terhadap berat basah akar tanaman buah naga. Grafik berat basah akar pada perlakuan panjang stek dan komposisi media tanam dapat dilihat pada Gambar 1.

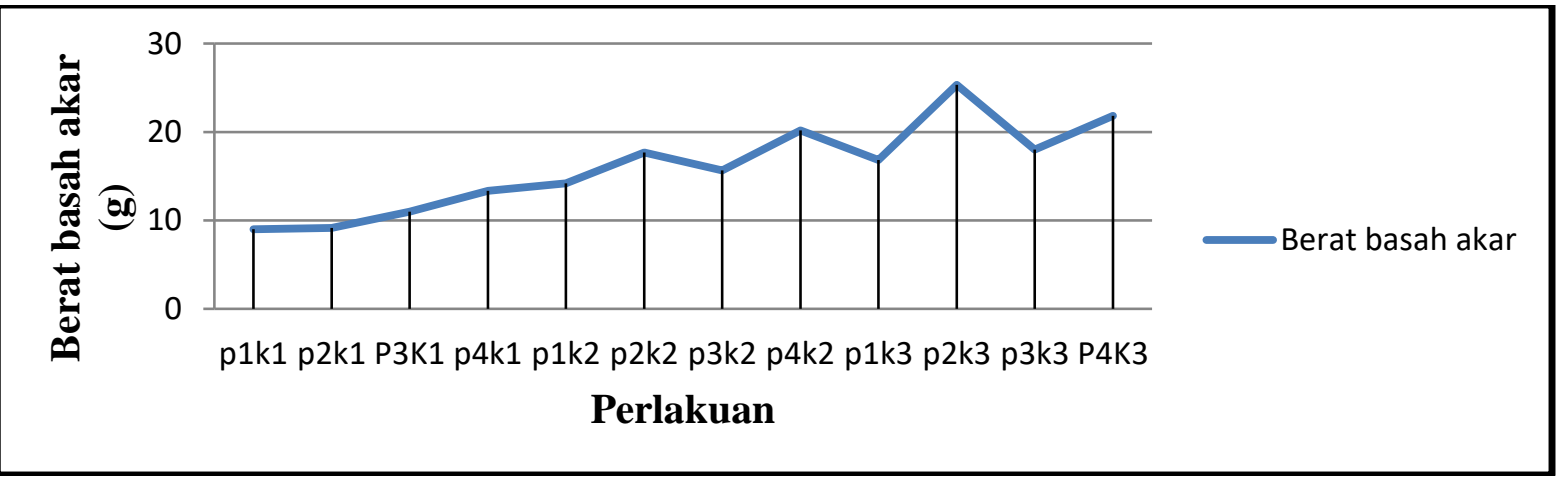

Gambar 1. Grafik berat basah akar (g) pada perlakuan panjang stek dan komposisi media tanam

Dari grafik dapat dilihat bahwa pada pengamatan berat basah akar tanaman buah naga bahwa perlakuan $\mathrm{p}_{2} \mathrm{k}_{3}$ menunjukkan rata-rata berat basah akar terbesar yaitu 25,33 g.

\section{Pembahasan}

\section{Panjang Stek}

Hasil analisis ragam menunjukan bawa perlakuan tunggal panjang stek tidak berpengaruh terhadap waktu munculnya tunas, jumlah tunas, panjang akar dan berat basah akar, kecuali panjang tunas berpengaruh nyata pada 12 MST. Hal ini diduga kerena adanya perbedaan jumlah cadangan makanan pada panjang stek yang berbeda, dengan demikian pada panjang stek yang lebih panjang terdapat cadangan makanan yang lebih banyak stek menimbulkan tingkat pertumbuhan yang berbeda pula. Cadangan makanan yang terdapat dalam stek akan diolah atau dirombak oleh tanaman itu sendiri yang akan digunakan untuk membentuk atau merangsang pertumbuhan sel-sel jaringan tanaman stek, yang pada akhirnya dapat mendukung aktivitas oragan-organ pertumbuhan seperti tunas, batang dan akar.

Menurut Guritno dan Sitompul (1995) dalam Komang, et. al, (2017) peristiwa pertumbuhan dapat dimulai dari perkecambahan biji atau bahan tanaman lain seperti stek. Setelah tanaman ditanam, substrat yang terdapat didalamnya (karbohidrat, lemak dan protein) akan mengalami perombakan secara enzimatik untuk mendukung aktivitas embrio atau tunas membentuk bakal tanaman yang kemudian membentuk organ-organ utama dalam tanaman seperti batang, daun, dan akar. Pembentukan awal dari organ-organ ini, kemudian tergantung dari cadangan karbohidrat dan unsur hara dalam biji atau stek serta efisiensi metabolisme. Tanaman kemudian tumbuh dan berkembang 
mengikuti aktivitas dari proses yang mendukung pertumbuhan disingkronisasi sedemikian rupa dalam membentuk biomassa tanaman yang maksimal sesuai dengan kondisi lingkungan.

Perlakuan panjang stek $\mathrm{p}_{3}(45 \mathrm{~cm})$ dan $\mathrm{p}_{4}(50 \mathrm{~cm})$ memberikan hasil tertinggi terhadap parameter pengamatan panjang tunas dan jumlah tunas, hal ini diduga karena semakin panjang stek maka semakin banyak cadangan makanan yang terdapat didalamnya, sehingga stek lebih panjang memiliki energi yang lebih banyak untuk pertumbuhannya, baik itu sebagai pembentukan tunas, daun, dan yang terpenting dalam pembentukan akar. Kandungan karbohidrat yang tinggi memudahkan stek untuk membentuk akar, karena laju pembelahan dan perpanjangan sel serta pertumbuhan jaringan lebih cepat. Cadangan makanan yang terdapat dalam stek akan diolah atau dirombak oleh tanaman itu sendiri yang akan digunakan untuk membentuk atau merangsang pertumbuhan sel-sel jaringan tanaman (stek), yang pada akhirnya dapat mendukung aktivitas oraganorgan pertumbuhan seperti tunas, batang dan akar (Harjadi 1993 dalam Komang, et. al, 2017).

Beberapa faktor yang juga mempengaruhi keberhasilan stek, yaitu asal stek (posisi stek pada tanaman induk), panjang stek, dan lingkungan (media pengakaran, suhu, dan kelembaban, cahaya). Selain ketersediaan bahan makanan yang cukup untuk pertumbuhan stek, diduga keadaan lingkungan (media pengakaran, suhu dan kelembaban cahaya) dan pemilihan bahan stek yang baik juga merupakan salah satu faktor keberhasilan tumbuhnya stek (Harjadi 1993 dalam Komang, et. al, 2017).

\section{Komposisi Media Tanam}

Hasil analisis ragam menunjukan bahwa perlakuan tunggal komposisi media tanam kotoran walet berpengaruh nyata pada waktu muncul tunas, jumlah tunas, panjang tunas dan panjang akar, kecuali berat basah akar tidak berpengaruh. Pemberian komposisi media tanam yang mengandung kotoran walet $1,0 \mathrm{~kg}$ tanah : $1,0 \mathrm{~kg}$ pupuk kotoran walet : 1,0 $\mathrm{kg}$ pasir $\left(\mathrm{k}_{2}\right)$ memberikan rata-rata panjang tunas $7,39 \mathrm{~cm}$ dan panjang akar 19,58 cm, tidak berbeda dengan pemberian komposisi media kotoran walet $0,5 \mathrm{~kg}$ tanah : $1,5 \mathrm{~kg}$ pupuk kotoran walet : $1,0 \mathrm{~kg}$ pasir $\left(\mathrm{k}_{3}\right)$ juga memberikan rata-rata panjang tunas $7,86 \mathrm{~cm}$ dan panjang akar $23,29 \mathrm{~cm}$. Pemberian komposisi media tanam yang mengandung kotoran walet dengan dosis yang paling tinggi 1,5 kg kotoran walet memberikan pengaruh terbaik terhadap pertumbuhan bibit buah naga. Hal ini diduga karena semakin banyak kotoran walet diberikan maka sifat fisik, kimia dan biologi tanah akan semakin lebih baik dalam mendukung pertumbuhan tanaman. Kotoran walet merupakan pupuk kandang yang baik untuk pertumbuhan tanaman, sama seperti guano, maka kotoran walet hasil sisa dari serangga yang dimakan oleh walet dan kotoran walet jenis pupuk yang lambat larut. Kotoran walet memiliki kandungan fosfor dan nitrogen yang tinggi (Lestari 2011).

Menurut Buckman dan Brady (1982) sifat fisika tanah berpengaruh langsung terhadap perakaran tanaman, air dan udara tanah. Disamping memberikan dukungan secara fisik pada tanaman, tanah merupakan sumber mineral dan air bagi tanaman. Kondisi tanah dan mineral dapat mempengaruhi pertumbuhan tanaman. Sifatsifat fisika tanah diketahui sangat mempengaruhi pertumbuhan dan produksi tanaman karena kondisi fisik tanah menentukan penetrasi akar di dalam tanah sehingga memudahkan akar tanaman menyerap air, retensi air, drainase, aerasi dan nutrisi tanaman yang mempengaruhi pertumbuhan tanaman.

Tunas memiliki sifat biologi sebagai tempat tumbuh tanaman dan tempat hidup organisme didalamnya menyediakan unsurunsur yang diperlukan oleh tanaman dan organisme lainnya. Di dalam tanah terjadi proses-proses yang menghasilkan sifat biologi tanah, misalnya adanya cacing tanah akan meningkatkan unsur nitrogen, fosfor, kalium, serta kalsium dalam tanah sehingga dapat meningkatkan kesuburan tanah dan ketersediaan unsur hara bagi tanaman. Selain dari sifat fisika dan biologi yang dapat 
mempengaruhi pertumbuhan tanaman yaitu sifat kimia (Buckman dan Brady 1982).

Sifat kimia tunas merupakan kandungan bahan organik, unsur hara, dan $\mathrm{pH}$ tanah, bahan organik, yang dimaksud dalam penelitian ini adalah kotoran burung walet. Kandungan bahan organik tanah mempengaruhi karakteristik tanah, pada tanah dengan kandungan bahan organik tinggi akan memberikan efek warna tanah coklat hingga hitam. Sifat kimia tanah yang lain berupa derajat keasaman atau $\mathrm{pH}$ tanah. $\mathrm{pH}$ tanah dikatakan normal dan baik untuk pertumbuhan tanaman yaitu antara 6,5 sampai dengan 7,5. Pada keadaan ini semua unsur hara pada larutan tanah dalam keadaan tersedia bagi pertumbuhan tanaman seperti unsur nitrogen, fospor dan kalium (Buckman dan Brady 1982).

Nitrogen juga memainkan peran yang penting dalam mempengaruhi pertumbuhan akar tanaman. Tanaman yang disuplai $\mathrm{N}$ berlebihan, akan membentuk perakaran yang dangkal, bercabang banyak dan pendekpendek. Tanaman yang memiliki sistem perakaran seperti ini akan rentan terhadap kekeringan (Wijaya 2008).

Fosfor mempunyai peran dalam memperbaiki pertumbuhan akar tanaman. Namun dalam hal memacu pertumbuhan memanjang akar lateral $P$ berperan jauh baik daripada N. Di dalam tanah kandungan $\mathrm{P}$ total bisa tinggi tetapi hanya sedikit yang tersedia bagi tanaman. Tanaman menambang unsur $\mathrm{P}$ dalam jumlah lebih kecil dibandingkan unsur N dan K (Wijaya 2008).

Purwati et al. (2007) bahwa rendahnya laju pertumbuhan akar di pot disebabkan keterbatasan ruang kontak akar dengan tanah sehingga pertumbuhan dan perkembangan akar terhambat yang menyebabkan laju pertumbuhan menjadi rendah dibanding dengan tanaman yang tumbuh di lapangan. Menurut Sitompul dan Guritno (1995) dalam Nurhadiah (2017) menyatakan bahwa berat basah tanaman dapat menunjukkan aktivitas metabolisme tanaman dan nilai berat basah tanaman dipengaruhi oleh kandungan air jaringan, unsur hara dan hasil metabolisme.

\section{Interaksi panjang stek dengan komposisi media tanam}

Hasil analisis ragam menunjukan bahwa interaksi panjang stek dengan komposisi media tanam tidak berpengaruh terhadap semua variabel pengamatan. Namun hasil menyatakan rata-rata menunjukan interaksi panjang stek dan komposisi media tanam menghasilkan waktu munculnya tunas tercepat, jumlah tunas, panjang tunas dan panjang akar terpanjang pada perlakuan $\left(\mathrm{p}_{4} \mathrm{k}_{3}\right)$, tetapi tidak berpengaruh terhadap interaksi panjang stek dan komposisi medi tanam. Hal ini diduga disebabkan kerena kandungan komposisi media tanam pada 2 MST belum terdekomposisi secara sempurna sehingga belum tersedia dalam tanah.

Tanah yang kaya bahan organik relatif lebih sedikit hara yang terfiksasi mineral tanah sehingga yang tersedia bagi tanaman lebih besar. Hara yang digunakan oleh mikroorganisme tanah bermanfaat dalam mempercepat aktivitasnya, meningkatkan kecepatan dekomposisi bahan karbohidrat dan protein (Sutanto 2002).

Setyamijaya (1986) dalam Nurhadiah (2017) mengatakan bahwa unsur nitrogen yang ada dalam pupuk organik mampu mempengaruhi pertumbuhan meristem untuk dapat berkembang. Menurut Wijaya (2008) juga mengatakan bahwa panjang tanaman dipengaruhi oleh pemberian nitrogen yang dapat meningkatkan tinggi tanaman.

Bahwa kandungan cadangan makanan (karbohidrat dan nitrogen) merupakan komponen yang sangan mempengaruhi dalam pembentukan akar pada stek. Pertumbuhan dan perkembangan akar dipengaruhi oleh kandungan bahan stek yang digunakan terutama persediaan dari karbohidrat dan nitrogen, stek yang mengandung karbohidrat yang tinggi dan nitrogen yang cukup akan membentuk akar dan tunas (Mangoendidjojo 2003 dalam Komang, et. al, 2017).

Terdapat beberapa faktor yang juga mempengaruhi keberhasilan stek, yaitu asal stek (posisi stek pada tanaman induk), panjang stek, dan lingkungan (media pengakaran, suhu, dan kelembaban cahaya) . Selain ketersediaan bahan makanan yang cukup untuk pertumbuhan stek, diduga keadaan lingkungan (media pengakaran, 
suhu dan kelembaban cahaya) dan pemilihan bahan stek yang baik juga merupakan salah satu faktor keberhasilan tumbuhnya stek (Harjadi 1989 dalam Andre, et. al,. 2012).

Media tanam yang tepat merupakan salah satu syarat keberhasilan budidaya tanaman khususnya budidaya dalam wadah. Keberhasilan pertumbuhan tanaman ditentukan oleh perkembangan akarnya. Akar tanaman hendaknya berada pada suatu lingkungan yang mampu memberikan tunjangan struktural, memungkinkan absorbsi air dan ketersediaan nutrisi yang memadai. Selain itu, media tanam memungkinkan drainase dan $\mathrm{pH}$ yang baik bagi tanaman (Ingels 1985 dalam Ramadan, et. al,. 2014).

\section{KESIMPULAN}

Interaksi antara panjang stek dan komposisi media tanam tidak berpengaruh pada semua variabel pengamatan pertumbuhan bibit buah naga; perlakuan panjang stek berpengaruh nyata terhadap panjang tunas bibit buah naga pada 12 MST; komposisi media tanam berpengaruh nyata terhadap waktu munculnya tunas, jumlah tunas, panjang tunas dan panjang akar bibit buah naga; tidak didapatkannya interaksi antara panjang stek dan komposisi media tanam bibit buah naga; didapatkan perlakuan panjang stek terbaik yang menunjukan panjang tunas bibit buah naga pada $12 \mathrm{MST}$ terpanjang yaitu $\mathrm{p}_{3}(45 \mathrm{~cm})$; dan didapatkan komposisi media tanam terbaik yaitu berpengaruh pada waktu munculnya tunas, jumlah tunas, panjang tunas dan panjang akar bibit buah naga $\mathrm{k}_{3}(0,5 \mathrm{~kg}$ tanah $: 1,5 \mathrm{~kg}$ pupuk kotoran walet : $1,0 \mathrm{~kg}$ pasir).

\section{DAFTAR PUSTAKA}

Anata, R., Nirwan Sahiri dan Andi Ete. 2014. Pengaruh berbagai komposisi media tanam dan pupuk kandang terhadap pertumbuhan dan hasil tanaman Daun Dewa (Gynura Pseudochina (L.)Dc). Jurnal Agrotekbis ISSN : 2338-3011.

Arifin, Z., Riyo Samekto, Dewi Ratna Nurhayati. 2015. Pengaruh media pupuk organik dan panjang stek terhadap pertumbuhan tanaman buah naga (Hylocereus polyrhizus). Jurnal Innofarm Volume 4, No. 1.

Buckman, H dan N.C Brady. 1982. Kesuburan Tanah dan Pemupukan Tanah Pertanian. Pustaka Buana. Bandung.

Emil, S. 2011. Untung Berlipat dari Bisnis Buah Naga Unggul. Lily Publisher. Yogyakarta.

Kesuma, K. A. G., Andi Ete dan Hamid Noer. 2017. Pengaruh berbagai jenis pupuk organik pada panjang stek yang berbeda terhadap pertumbuhan bibit buah naga (Hylocereus Costaricensis). e-J.Agrotekbis Volume 5, No. 1. ISSN :2338-3011.

Kristanto, D. 2009. Buah Naga Pembudidayaan di Pot dan Kebun. Penebar Swadaya. Jakarta.

Lestari. 2011. Pupuk majemuk organik guano wallet. http://id528084201011.indonetwork.c o.id/. Diakses 20 Oktober 2018.

Novitasari, B.., Meiriani, dan Haryati. 2015. Pertumbuhan stek tanaman buah naga (Hylocereus costaricensis (Web.) Britton \& Rose) dengan pemberian kombinasi Indole Butyric Acid (IBA) dan Naphthalene Acetic Acid (NAA). Jurnal Agroekoteknologi Volume 4. No. 1. E-ISSN No. 2337-6597.

Nurhadiah. 2017. Pengaruh pemberian kotoran burung walet terhadap pertumbuhan dan hasil bayam merah (Alternanthera amoena Voss). Tesis. Fakultas Pertanian Universitas Kapuas Sintang. Kapuas.

Purwati, S., Soetopo, R., setiawan, S. 2007. Potensi penggunaan abu boiler industri pulp dan kertas sebagai bahan pengkondisi tanah gambut pada arel hutan tanaman industri. Jurnal Berita Selulosa Vol. 42. No. 1. Hal 8-17. 
Sparta, A., Mega Andini dan Taupik Rahman. 2012. Pengaruh berbagai panjang stek terhadap pertumbuhan bibit buah naga (Hylocereus polyryzus). Balai Penelitian Tanaman Buah Tropika. Balai Pengkajian Teknologi Pertanian Bengkulu. Bengkulu.

Sutanto, R. 2002. Penerapan Pertanian Organik. Kanisius. Yogyakarta.

Wijaya, K.A. 2008. Nutrisi Tanaman Sebagai Penentu Kualitas Hasil Dan Resistensi Alami Tanaman. Prestasi Pustaka. Jakarta.

Winten, K. T. I., Anak Agung Gede Putra dan Pande Gede Gunamanta. 2017. Pengaruh panjang dan lingkar stek terhadap pertumbuhan bibit tanaman buah naga. Jurnal GaneÇ Swara Volume 11 No.2.

Yanti, A. A. 2008. Kajian media tanam dan konsentrasi BAP terhadap pertumbuhan stek tanaman buah naga daging putih (Hylocereus undatus). Tesis. Program Pascasarjana Program Studi Agronomi Universitas Sebelas Maret. Surakarta.

Yunanda, J, Murniati dan Sri Yoseva. 2015. Pertumbuhan stek batang tanaman buah naga (Hylocereus Costaricensis) dengan pemberian beberapa konsentrasi urine sapi. Jurnal Online Mahasiswa Fakultas Pertanian Volume 2. No. 1. 